\title{
PENGARUH PEMBELAJARAN E-LEARNING BERBASIS EDMODO TERHADAP MINAT DAN HASIL BELAJAR MAHASISWA PGSD STKIP MUHAMMADIYAH MUARA BUNGO
}

\author{
Puput Wahyu Hidayat ${ }^{1}$, Abdulah ${ }^{2}$ \\ STKIP Muhammadiyah Muara Bungo, Komplek Islamic Center Kabupaten Bungo ${ }^{1,2}$ \\ puputwahyuhidayat@gmail.com
}

\begin{abstract}
ABSTRAK
Ranah kognitif dan afektif mahasiswa harus diperhatikan, salah satunya adalah hasil dan minat belajar matematika. Mahasiswa yang memiliki minat yang baik dalam pembelajaran, akan mendapatkan hasil yang memuaskan. Sehingga, antara sisi kognitif dan afektif dapat berjalan seimbang. Untuk mendapatkan hasil akhir yang maksimal antara minat dan hasil belajar mahasiswa, pembelajaran harus dilakukan dengan menyesuaikan perkembangan teknologi saat ini. Usaha yang dapat dilakukan dalam meningkatkan minat dan hasil belajar mahasiswa adalah dengan memilih pendekatan pembelajaran yang baik. Minat dan hasil belajar mahasiswa dapat dioptimalkan jika dilakukan dengan pembelajaran yang tepat, salah satunya adalah dengan pembelajaran mebggunakan pendekatan berbasis teknologi, yaitu pendekatan pembelajaran berbasis Edmodo. Oleh karena itu, perlu dilakukan penelitian tentang pembelajaran yang mampu meningkatkan minat dan hasil belajar yang berbasis teknologi, yaitu pembelajaran dengan menggunakan Edmodo. Tujuan penelitian ini adalah untuk mengetahui pengaruh pendekatan pembelajaran e-learning berbasis Edmodo terhadap minat belajar dan hasil belajar Mahasiswa PGSD STKIP Muhammadiyah Muara Bungo. Jenis penelitian ini adalah penelitian quasi experiment dengan designpretest-posttest nonequivalent group design. Penelitian ini telah dilaksanakan di Prodi PGSD STKIP Muhammadiyah Muara Bungo Tahun 2019. Instrumen yang digunakan untuk mengukur minat belajar berupa angket minat belajar sebanyak 30 pernyataan, dan tes hasil belajar matematika siswa. Data di analisis dengan menggunakan uji analisis deskriptif dan uji analisis inferensial yang meliputi uji normalitas, homogenitas dan uji hipotesis. Hasil penelitian menunjukkan, terdapat pengaruh yang signifikan dengan pembelajaran elearning berbasis edmodo terhadap hasil belajar serta minat berlajar mahasiswa.
\end{abstract}

Kata kunci :

Edmodo; Hasil Belajar; Minat Belajar

\begin{abstract}
The cognitive and affective domains of students must be considered, one of which is the results and interest in learning mathematics. Students who have a good interest in learning, will get satisfying results. So that, between the cognitive and affective sides can walk in balance. To get the maximum results between interests and student learning outcomes, learning must be done by adjusting current technological developments. Efforts that can be made in increasing student interest and learning outcomes are by choosing a good learning approach. Interest and student learning outcomes can be optimized if done with appropriate learning, one of which is by using a technology-based learning approach, which is Edmodo-based learning approach. Therefore, it is necessary to conduct research on learning that is able to increase interest and learning outcomes based on technology, namely learning by using Edmodo. The purpose of this study was to determine the effect of Edmodo-based e-learning learning approaches on learning interest and learning outcomes of PGSD STKIP Muhammadiyah Muara Bungo students. This type of research is a quasi-experimental study with a pretest-posttest nonequivalent group design. This research has been carried out at the STKIP Muhammadiyah Muara Bungo PGSD Study Program in 2019. The instrument used to measure interest in learning took the form of a questionnaire of 30 interest in learning, and a test on student mathematics learning outcomes. Data were analyzed using descriptive analysis test and inferential analysis test which included tests of normality, homogeneity and hypothesis testing. The results showed that there was a significant influence with edmodo-based learning based on learning outcomes and student interest in learning.
\end{abstract}

Keywords :

Edmodo; Learning Interest; Learning Outcome 


\section{PENDAHULUAN}

Pembelajaran matematika merupakan pelajaran yang wajib dilakukan oleh semua kalangan masyarakat, baik anak kecil hingga orangtua. Matematika sangat penting untuk mendukung kehidupan semua manusia. Tanpa adanya matematika, manusia akan merasa kesulitan dalam menjalani kehidupannya. Sementara itu, dalam belajar matematika, dibutuhkan suatu minat belajar yang berasal dari dalam diri maupun dari luar. Menurut Slameto (2013), dalam kegiatan pembelajaran hasil dan proses pelaksanaan dipengaruhi oleh beberapa faktor, yaitu faktor intern dan faktor ekstern. Faktor intern adalah faktor yang ada dalam diri individu yang sedang belajar, sedangkan faktor ekstern adalah faktor yang ada di luar individu. Dalam hal ini faktor intern yang mempengaruhi belajar salah satunya meliputi minat belajar. Minat merupakan salah satu faktor yang sangat mendasar dan sangat penting bagi mahasiswa dalam suatu pembelajaran karena dengan adanya minat belajar mahasiswa, maka akan dapat menentukan keberhasilan suatu pembelajaran. Selain itu, minat belajar juga merupakan salah satu faktor yang kuat dalam menentukan keberhasilan seseorang. Oleh karena itu agar berhasil dalam setiap usaha seseorang harus memupuk minat terhadap apa yang diinginkan, dengan adanya minat yang besar, seseorang akan berusaha untuk memperoleh hasil yang memuaskan dan maksimal meski banyak halangan yang akan dilauinya.

Selanjutnya, Slameto (2010) berpendapat bahwa minat sebagai kecenderungan yang tetap untuk memperhatikan terus menerus disertai rasa senang. Seseorang yang menyukai sesuatu hal, maka akan mendapatkan hal tersebut dengan maksimal. Salah satu tujuan pembelajaran yang ingin dicapai dalam suatu kegiatan pembelajaran adalah pemahaman terhadap matakuliah.
Selain itu, untuk mengetahui berhasil atau tidak suatu pembelajaran juga dapat dilihat dari kemampuan pemahaman mahasiswa. Jika mahasiswa tidak memahami konsep dasar dalam proses pembelajaran, maka mahasiswa tersebut akan merasa kesulitan untuk mengikuti matakuliah lanjutan. Hasil Belajar merupakan suatu peningkatam kemampuan siswa yang diperoleh dalam proses pembelajaran yang berupa angka atau nilai. Sehingga, dibutuhkan proses pembelajaran yang baik supaya hasil belajar sesuai dengan yang diharapkan.

Matematika merupakan mata pelajaran yang sangat penting diajarkan untuk semua tingkatan pendidikan. Matematika diajarkan mulai dari tingkat pra sekolah dasar hingga perguruan tinggi. Bahkan semua perguruan tinggi yang meliputi berbagai bidang dari bidang pendidikan sampai bidang ilmu terapan semuanya mempelajari tentang matematika. Namun, hingga sekarang matematika merupakan mata pelajaran yang sulit dipelajari, membosankan untuk dipelajari, bahkan sebagian mahasiswa menganggap matematika menakutkan dengan dosen atau dosen yang killer. Pernyataan yang seperti ini tidak bisa disalahkan dan tidak berlebihan selain mempunyai sifat yang abstrak, matematika memerlukan pemahaman yang baik.

Moedjiono dan Dimyanti (2013:7) berpendapat bahwa, "hasil belajar adalah hasil dari interaksi tindak belajar murid dan tindak mengajar yang dilakukan oleh dosen, tindak mengajar diakhiri dengan proses evaluasi, sedang tindak belajar merupakan puncak dari proses belajar dengan meningkatnya kemampuan".

Menurut Sudjana (2009: "mendefinisikan hasil belajar siswa pada hakikatnya adalah perubahan tingkah laku sebagai hasil belajar dalam pengertian yang lebih luas mencakup bidang kognitif, afektif dan psikomotor". Hasil belajar 


\section{$\pi$ (Phi)}

melingkupi tiga aspek, yaitu kognitif yang merupakan kecerdasan mahasiswa, afektif merupakan tingkah laku serta pskiomotor merupakan keterampilan yang dimiliki oleh mahasiswa.

Sementara itu menurut Hamalik (2011: 31) hasil belajar adalah pola-pola perbuatan, nilai-nilai, pengetahuanpengetahuan, sikap-sikap, apresiasi, abilitas, dan keterampilan. Hasil belajar meliputi banyak aspek yang harus dihasilkan.

Dalam pembelajaran matematika, ketika mahasiswa diberikan soal yang berbeda dengan contoh masih terlihat banyak mahasiswa yang masih kebingungan dalam menyelesaikan soal yang diberikan oleh dosen. Sehingga, setiap mahasiswa diwajibkan untuk memiliki minat yang serius dalam belajar sehingga hasil belajar yang diharapkan akan lebih baik, sehingga mahasiwa dapat menguasai pembelajaran matematika dengan baik.

Sementara itu, perkembangan ilmu pengetahuan dibidang teknologi, sangat mempengaruhi gaya hidup manusia. Dalam hal ini, masyarakat yang kehidupannya dekat dengan segala perkembangan teknologi yang kemudian berimbas pada perubahan karakter berpikir masyarakat di segala bidang (Uno, 2011:91). Saat ini muncul satu sistem pembelajaran yang relatif baru di Indonesia yang disebut elearning. Elearning atau pembelajaran melalui online adalah pembelajaran yang pelaksanaannya didukung oleh jasa teknologi seperti telepon, audio, videotape, telekonferense, trasmisi satelit, bahkan web, yang semuanya menggunakan media komputer online (Uno, 2011:109).

Edmodo bisa didownload melalui Playstore sehingga berbentuk suatu aplikasi. Aplikasi merupakan penerapan, penggunaan atau penambahan, atau aplikasi merupakan software yang berfungsi untuk melakukan berbagai bentuk pekerjaan atau tugas-tugas tertentu seperti penerapan dan penggunaan suatu data (Anisyah, 2000:34).

Sementara itu, menurut (Dhanta, 2009:65) aplikasi (application) merupakan software yang dibuat oleh suatu perusahaan komputer untuk mengerjakan tugas-tugas tertentu, misalnya Microsoft Word, Microsoft Excel. Menurut (Buyens, 2001:25), aplikasi adalah satu unit perangkat lunak yang dibuat untuk melayani kebutuhan akan beberapa aktivitas.

Menurut (Kristanto, 2004), perangkat lunak merupakan produk yang seharusnya dirancang dan dibangun lewat suatu aktivitas rekayasa perangkat lunak yang berdisiplin dan sistematis. Dalam arti yang luas, perangkat lunak terdiri dari programprogram yang dibuat oleh komputer dengan bermacam arsitektur, dokumen-dokumen berupa hard-copy dan bentuk-bentuk maya, dan data berupa angka-angka dan teks juga representasi informasi gambar, video dan audio.

Sedangkan menurut Pressman (2012:20), perangkat lunak adalah merupakan perintah dari program computer yang ketika dijalankan menyediakan bermacam-macam fitur, struktur data yang memungkinkan program dalam memanipulasi informasi, dan informasi deskriptif pada salinan tercetak dan memiliki bentuk maya yang menggambarkan pengoperasian dan penggunaan program-program. Dari pengertian para ahli tersebut, dapat disimpulkan bahwa aplikasi merupakan software yang berfungsi untuk melakukan berbagai bentuk pekarjaan atau tugas-tugas tertentu seperti penerapan, penggunaan dan penambahan data.

Salah satu tujuan pembelajaran yang ingin dicapai dalam suatu kegiatan pembelajaran adalah pemahaman terhadap matakuliah. Selain itu, untuk mengetahui berhasil atau tidak suatu pembelajaran juga dapat dilihat dari kemampuan pemahaman mahasiswa. Jika mahasiswa tidak memahami konsep dasar dalam proses pembelajaran, maka mahasiswa tersebut 


\section{$\pi$ (Phi)}

akan merasa kesulitan untuk mengikuti matakuliah lanjutan. Hasil Belajar merupakan suatu peningkatam kemampuan siswa yang diperoleh dalam proses pembelajaran yang berupa angka atau nilai. Sehingga, dibutuhkan proses pembelajaran yang baik supaya hasil belajar sesuai dengan yang diharapkan.

Matematika merupakan mata pelajaran yang sangat penting diajarkan untuk semua tingkatan pendidikan. Matematika diajarkan mulai dari tingkat pra sekolah dasar hingga perguruan tinggi. Bahkan semua perguruan tinggi yang meliputi berbagai bidang dari bidang pendidikan sampai bidang ilmu terapan semuanya mempelajari tentang matematika. Namun, hingga sekarang matematika merupakan mata pelajaran yang sulit dipelajari, membosankan untuk dipelajari, bahkan sebagian mahasiswa menganggap matematika menakutkan dengan guru atau dosen yang killer. Pernyataan yang seperti ini tidak bisa disalahkan dan tidak berlebihan selain mempunyai sifat yang abstrak, matematika memerlukan pemahaman yang baik.

Moedjiono dan Dimyanti (2013:4) berpendapat bahwa, "hasil belajar adalah hasil dari interaksi tindak belajar murid dan tindak mengajar yang dilakukan oleh guru, tindak mengajar diakhiri dengan proses evaluasi, sedang tindak belajar merupakan puncak dari proses belajar dengan meningkatnya kemampuan".

Dalam pembelajaran matematika, mahasiswa yang diberikan soal yang berbeda dengan contoh masih terlihat banyak mahasiswa yang masih kebingungan dalam menyelesaikan soal yang diberikan oleh dosen. Sehingga, setiap mahasiswa diwajibkan untuk memiliki minat yang serius dalam belajar sehingga hasil belajar yang diharapkan lebih baik dan mahasiwa dapat menguasai pembelajaran matematika dengan baik.

Sementara itu, berdasarkan pengalaman mengajar di kelas Pendidikan
Guru Sekolah Dasar STKIP Muhammadiyah Muara Bungo terlihat pada saat kelompok presentasi di depan, mahasiswa lain terlihat ribut diskusi. Selanjutnya, terkadang waktu yang di buat untuk mencari jawaban terlalu lama sehingga membuat mahasiswa kelas tidak kondusif. Waktu yang seperti ini sangat disayangkan sekali, karena terbuang sia-sia. Selanjutnya, waktu yang dimiliki dosen untuk menyimpulkan matakuliah sangat sedikit karena sudah habis untuk diskusi.

Selain itu menurut Sardiman (2011:76), minat diartikan sebagai suatu kondisi yang terjadi apabila seseorang melihat ciri-ciri atau arti sementara situasi yang dihubungkan dengan keinginankeinginan atau kebutuhan-kebutuhannya sendiri. Dari bebera papengertian diatas dapat dikatakan bahwa minat adalah kecenderungan tertarik pada sesuatu yang relatif tetap untuk lebih memperhatikan dan mengingat secara terus-menerus yang diikuti rasa senang.

Sementara itu menurut Hidayat (2018: 65), suatu pendekatan dalam kegiatan pembelajaran pada hakikatnya merupakan sarana untuk mencapai tujuan pembelajaran serta dapat meningkatkan aktivitas belajar yang dilakukan guru dan siswa, dan salah satu pendekatan pembelajaran yang inovativ tersebut dapat memberikan peluang bagi siswa untuk meningkatkan minat belajar. Menurut Muhson (2009: 171), berdasar hasil pantauan selama perkuliahan, mata kuliah menghitung dianggap mahasiswa sebagai mata kuliah yang cukup menakutkan. Hal ini didasarkan karena materinya lebih banyak yang bersifat harus banyak berfikir. Bagi mahasiswa yang memiliki kemampuan kuantitatif yang rendah, maka mata kuliah tersebut menjadi tidak menarik. Akibatnya minat belajar mahasiswa terhadap mata kuliah ini menjadi rendah.

Dengan pendekatan pembelajaran elearning berbasis edmodo, maka pembelajaran matematika harus 


\section{$\pi$ (Phi)}

dipersiapkan secara matang oleh dosen, dan menjadikan mahasiswa semakin termotivasi dan berminat dalam melakukan kegiatan pembelajaran matematika di kampus. Karena pendekatan dalam pembelajaran pada hakikatnya merupakan sarana untuk mencapai tujuan pembelajaran serta dapat meningkatkan aktivitas belajar yang dilakukan pendidik dan mahasiswa. Salah satu pendekatan pembelajaran tersebut yang memberikan peluang bagi mahasiswa untuk meningkatkan minat dan hasil belajar mahasiswa adalah pendekatan pembelajaran elearning berbasis edmodo.

Pendekatan pembelajaran elearning berbasis edmodo dijadikan alternatif strategi belajar yang lebih memberdayakan mahasiswa, merupakan konsep belajar yang membantu pendidik mengaitkan materi pembelajaran, tugas mandiri mauapun terstruktur serta memberikan kuis pada saat pembelajaran sangat disarankan dalam zaman milenial seperti sekarang ini. Konsep tersebut, diharapkan pembelajaran lebih bermakna bagi mahasiswa dan mampu meningkatkan minat sehingga memicu keberhasilan dalam kegiatan pembelajaran matematika.

Edmodo merupakan suatu pendekatan pembelajaran yang aktif, kreatif, dan menarik berbasiskan teknologi informasi telah dikembangkan oleh Jeff'O Hara sejak tahun 2008 melalui jejaring sosial pembelajaran yang dinamakan edmodo. Edmodo merupakan platform media sosial, seperti facebook yang dikembangkan khusus untuk siswa dan dosen dalam suatu ruangan kelas virtual yang dapat berfungsi untuk melaksanakan pembelajaran yang menarik dan mudah digunakan. Edmodo membuat pembelajaran menjadi dapat diselenggarakan dimana saja dan kapan saja tidak terbatas ruang dan waktu. Penggunaan edmodo membuat siswa secara aktif dapat berpartisipasi karena belajar online menyediakan lingkungan belajar interaktif. Siswa dapat memperoleh informasi berupa dokumen elektronik untuk memperkaya studi mereka. Selain itu, siswa mampu berkomunikasi langsung dengan teks, gambar, suara, data dan audio video melalui edmodo dan interaksi yang dihasilkan dapat menciptakan suasana belajar yang baik.

Berdasarkan uraian latarbelakang, maka penelitian ini penting untuk dilakukan untuk mengetahui pengaruh pendekatan pembelajaran elarning berbasis edmodo terhadap minat dan hasil belajar mahasiswa Prodi PGSD STKIP Muhammadiyah Muara Bungo. Sehingga dengan memiliki minat belajar yang baik, mahasiswa akan mampu mengerjakan soalsoal matematika dengan baik pula sehingga hasil belajar dapat meningkat. Dilain sisi, hasil dari penelitian ini diharapkan dapat menjadi referensi pendekatan pembelajaran yang tepat serta sebagai bahan kajian yang dapat dipublikasikan dalam jurnal nasional.

Berdasarkan latar belakang masalah yang telah diuraikan, rumusan masalah pada penelitian ini adalah bagaimana pengaruh pendekatan pembelajaran elearning berbasis edmodo terhadap kemampuan minat dan hasil belajar mahasiswa Prodi PGSD STKIP Muhammadiyah Muara Bungo. Tujuan penelitian untuk menganalisis pengaruh pendekatan pembelajaran elearning berbasis edmodo terhadap kemampuan minat dan hasil belajar mahasiswa Prodi PGSD STKIP Muhammadiyah Muara Bungo.

\section{METODE PENELITIAN}

Jenis penelitian ini adalah penelitian eksperimen semu (quasi experiment). Jenis penelitian ini dipilih karena peneliti tidak membuat kelas-kelas baru tetapi menggunakan kelas-kelas yang sudah ada. Desain dalam penelitian ini adalah pretestposttest non-equivalent group design. Sementara itu alur penelitian tersebut antaralain; (1) studi lapangan, peneliti melakukan observasi di Kampus STKIP Muhammadiyah Muara Bungo yang dalam 


\section{$\pi$ (Phi)}

kegiatan pembelajaran belum ada dosen yang menggunakan aplikasi Edmodo. Sehingga peneliti memiliki gambaran umum untuk melakukan suatu penelitian. (2) Identifikasi masalah, fokus penelitian berkaitan dengan bagaimana pengaruh pembelajaran e-learning berbasis Edmodo terhadap minat dan hasil belajar mahasiswa PGSD STKIP Muhammadiyah Muara Bungo. (3) Tujuan penelitian, untuk menganalisis pengaruh pendekatan pembelajaran elearning berbasis edmodo terhadap kemampuan minat dan hasil belajar mahasiswa Prodi PGSD STKIP Muhammadiyah Muara Bungo. Sementara itu, populasi pada penelitian ini adalah seluruh mahasiswa Prodi PGSD STKIP MB tahun akademik 2018/2019 dan menentukan sampel secara acak dari 4 kelas dan dipilih 2 kelas sebagai kelas eksperimen dan kelas konvensional. (4) Pengumpulan data, adalah cara-cara yang digunakan untuk mengumpulkan data. Data penelitian ini dikumpulkan melalui tes dan nontes untuk kedua kelompok eksperimen. Tes digunakan untuk mengukur hasil belajar. (a). Variabel Penelitian, penelitian ini terdiri atas dua variabel yaitu variabel bebas berupa pembelajaran berbasis Edmodo dan variabel terikat berupa minat dan hasil belajar. Kedua variabel penelitian ini akan diterapkan pada mahasiswa Prodi PGSD STKIP MB. (b) Instrumen penelitian, yaitu berupa soal tes hasil belajar dan angket minat belajar. Soal tes hasil belajar digunakan adalah soal dalam bentuk pilihan ganda (10 butir soal) dan esay (5 butir soal). Sementara itu untuk mengukur minat belajar digunakan angket yang terdiri dari 30 butir pernyataan. (c) Validitas, adalah suatu derajat ketetapan instrumen (alat ukur), maksudnya apakah instrumen yang digunakan betul-betul tepat mengukur apa yang akan diukur. Instrumen yang valid atau sahih mempunyai validitas yang tinggi, sebaliknya instrumen yang kurang valid berarti memiliki validitas rendah. (5) Analisis data, Teknik analisis data meliputi uji analisis deskriptif, uji analisis inferensial yang mencakup uji normalitas, uji homogenitas, dan uji hipotesis statistik. (a) Uji analisis deskriptif, yang digunakan untuk mendeskripsikan data yang diperoleh dari hasil posttest yaitu mean/nilai rata-rata, median/nilai tengah, modus, range/rentang, dan standard deviation/simpangan baku. Penelitian ini dilakukan dengan bantuan menggunakan bantuan Microsoft Excel 2013. (b) Uji prasyarat analisis inferensial, dilakukan untuk menguji hipotesis dengan menggunakan uji-t. Sebelum pengujian hipotesis, terlebih dahulu dilakukan uji normalitas dan uji homogenitas. Uji normalitas data menggunakan Microsoft Excel 2013 dengan menggunakan teknik Kolmogorov Smirnov. Uji homogenitas dengan menggunakan Fisher F. Data dapat dikatakan homogen apabila $P$ Value (2 tailed)>0,05. (6) Uji hipotesis penelitian, digunakan untuk mengetahui adanya pengaruh pembelajaran berbasis Edmodo terhadap hasil dan minat belajar mahasiswa dibandingkan dengan yang menggunakan model pembelajaran konvensional. Pengujian hipotesis ini dilakukan dengan bantuan program SPSS 20 for Windows yaitu dengan teknik analisis Paired Samples T-Test. Taraf signifikan uji sampel bebas Paired- Samples T-Test adalah 0,05, sedangkan convidence interval 95\%. Uji hipotesis dengan uji kesamaan dua rata-rata dilakukan untuk mengetahui apakah terdapat perbedaan rata-rata secara signifikan antara hasil posttest dua sampel penelitian. Nilai rata-rata kedua kelompok signifikansi (2tailed) di bawah 0,05. Jadi, hasilnya signifikan atau hipotesis diterima, sebaliknya bila signifikansi (2-tailed) lebih besar dari probabilitas di atas 0,05 maka hasilnya tidak signifikan sehingga hipotesis ditolak..

\section{HASIL DAN PEMBAHASAN}

\section{Deskrpsi Hasil Penelitian}

Deskripsi data yang dilakukan adalah deskripsi data tentang minat belajar matematika dan hasil belajar siswa. Minat belajar diperoleh dari instrumen yang 


\section{$\pi$ (Phi)}

berbentuk checklist dalam skala Likert, data tersebut dianalisis dengan statistik deskriptif. Analisis deskriptif yang dilakukan hanya untuk memperoleh skor minat belajar matematika siswa, sedangkan hasil belajar siswa diperoleh dari instrument tes hasil belajar. Selanjutnya, digolongkan berdasarkan skor baku, penyekoran angket minat belajar dalam penelitian disesuaikan dengan jumlah butir pernyataan angket minat. Sehingga dengan 30 butir pernyataan yang ada dalam angket, dapat ditentukan skor terendah dan tertingginya, maka

rentang penyekoran angket minat memiliki rentang antara 30 sampai dengan 150 . Untuk menentukan kriteria hasil pengukurannya digunakan klasifikasi berdasarkan rata-rata ideal $(\overline{\mathrm{X}} \mathrm{i})$ dan Standar Deviasi (Sbi).

$$
\overline{\mathrm{X}} \mathrm{i}=\frac{(30+150)}{2}=90, \text { dan } \mathrm{Sb}_{\mathrm{i}}=\frac{(150-30)}{6}=20
$$

Setelah memperoleh data pengukuran minat belajar siswa, total skor masingmasing unit dikategorikan berdasarkan pada Tabel. 1 berikut ini:

Tabel 1. Interval kriteria minat belajar

\begin{tabular}{ccc}
\hline Interval & Skor $(\mathrm{X})$ & Kriteria \\
\hline $\mathrm{X}>\left(\overline{\mathrm{X}} \mathrm{i}+1,8 \quad \mathrm{Sb}_{\mathrm{i}}\right)$ & $\mathrm{X}>126$ & Sangat tinggi \\
\hline$(\overline{\mathrm{X}} \mathrm{i}+0,6 \mathrm{Sbi})<\mathrm{X} \leq\left(\overline{\mathrm{X}} \mathrm{I}+1,8 \mathrm{Sb}_{\mathrm{i}}\right)$ & $102<\mathrm{X} \leq 126$ & Tinggi \\
\hline$(\overline{\mathrm{X}} \mathrm{i}-0,6 \mathrm{Sbi})<\mathrm{X} \leq\left(\overline{\mathrm{X}} \mathrm{i}+0,6 \mathrm{Sb}_{\mathrm{i}}\right)$ & $78<\mathrm{X} \leq 102$ & Sedang \\
\hline$(\overline{\mathrm{X}} \mathrm{i}-1,8 \mathrm{Sbi})<\mathrm{X} \leq\left(\overline{\mathrm{X}} \mathrm{i}-0,6 \mathrm{Sb}_{\mathrm{i}}\right)$ & $54<\mathrm{X} \leq 78$ & Rendah \\
\hline $\mathrm{X} \leq(\overline{\mathrm{X}} \mathrm{i}-1,8 \mathrm{Sbi})$ & $\mathrm{X} \leq 54$ & Sangat rendah \\
\hline
\end{tabular}

Sementara itu, untuk data hasil belajar pendeskripsian dilakukan untuk mengetahui data hasil belajar siswa pada saat peneltian. Adapun dalam penelitian ini menggunakan penelitian pengaruh yang bertujuan untuk menemukan ada tidaknya pengaruh pendekatan berbasis edmodo terhadap hasil belajar siswa. Data tentang hasil belajar siswa diperoleh melalui pengukuran dengan instrumen tes soal hasil belajar yang berupa 10 buah soal pilihan ganda dan 5 soal uraian. Sehingga skor yang diperoleh dikonversi menjadi nilai

dengan rentang antara 0 sampai dengan 100.

Data diperoleh dari instrument yang berbentuk tes pilihan ganda dan uraian selanjutnya data dianalisis dengan statistik deskriptif. Kemudian tingkat hasil belajartersebut ditentukan menggunakan kriteria hasil pengukuran dengan mengkategorikan hasil belajar sesuai dengan standar yang ditetapkan oleh departemen pendidikan dan kebudayaan Tahun 2013 dan diadopsi oleh standar kurikulum STKIP Muhammadiyah Muara Bungo sebagai berikut:

Tabel 2. Kriteria Penilaian Hasil Belajar

\begin{tabular}{ccc}
\hline No. & Tingkat Penguasaan & Kriteria \\
\hline 1 & $80-100$ & Sangat tinggi \\
2 & $70-79$ & Tinggi \\
3 & $60-69$ & Sedang \\
4 & $50-59$ & Rendah \\
5 & $0-49$ & Sangat rendah \\
\hline
\end{tabular}

*) sumber data: STKIP-MB

Berikut adalah ringkasan statistik deskriptif mengenai hasil belajar siswa awal dan akhir siswa dengan menerapakan pendekatan pembelajaran elearning berbasis edmodoterhadap hasil belajar siswa. 
Tabel 3. Data Hasil Belajar

\begin{tabular}{|c|c|c|c|c|}
\hline \multirow{2}{*}{ Deskripsi } & \multicolumn{2}{|c|}{ Kelas Eksperimen } & \multicolumn{2}{|c|}{ Kontrol } \\
\hline & Pretest & Posttest & Pretest & Posttest \\
\hline Nilai rata-rata & 67.38 & 79.44 & 59.26 & 70.71 \\
\hline Nilai maksimum & 87.00 & 94.00 & 78 & 82 \\
\hline Nilai minimum & 45.00 & 68.00 & 40 & 50 \\
\hline StandarDeviasi & 12.09 & 7.71 & 11.30 & 8.91 \\
\hline NilaiMaksimum Ideal & 100 & 100 & 100 & 100 \\
\hline Nilai Minimum Ideal & 0 & 0 & 0 & 0 \\
\hline Jumlah siswa & \multicolumn{2}{|c|}{32} & \multicolumn{2}{|c|}{28} \\
\hline
\end{tabular}

*) sumber data: hasil tes

Berdasarkan hasil analisis statistic deskriptif pada Tabel 3, menunjukkan bahwa pada kelompok eksperimen terdapat peningkatan skor rata-rata hasil belajar sebelum perlakuan yaitu sebesar 12,06 dari 67,38 menjadi 79,44. Sementara pada kelas kontrol terjadi peningkatan sebesar 11,45 dari 59,26 menjadi 70,71. Nilai tertinggi pada pretest dari kelas eksperimen sebesar 87,00 dan nilai terendah sebesar 45, sedangkan pada hasil posttest nilai tertinggi sebesar 94,00 dan nilai terendah sebesar

Berikut adalah ringkasan statistik deskriptif mengenai hasil belajar siswa awal dan akhir siswa dengan menerapakan
68. Sementara itu pada kelas kontrol, nilai terendah hasil pretest sebesar 40 dan nilai tertinggi sebesar 78, sedangkan pada kelas kontrol nilai terendah hasil posttest sebesar 50 dan nilai tertinggi sebesar 82 .

Selanjutnya, data minat belajar matematika siswa yang dideskripsikan pada penelitian ini terdiri atas data awal dan akhir. Deskripsi minat belajar baik pada kelas eksperimen maupun kelas kontrol terlihat pada tabel berikut ini:

pendekatan pembelajaran elearning berbasis edmodoterhadap hasil belajar siswa.

Tabel 4.Data Minat Belajar

\begin{tabular}{lcccr}
\hline \multirow{2}{*}{ Deskripsi } & \multicolumn{2}{c}{ Kelas Eksperimen } & \multicolumn{2}{c}{ Kontrol } \\
\cline { 2 - 5 } & Pretest & Posttest & Pretest & Posttest \\
\hline Nilai rata-rata & 109.41 & 125.47 & 96.61 & 107.78 \\
Nilai maksimum & 124 & 135 & 113 & 117 \\
Nilai minimum & 98 & 119 & 81 & 97 \\
StandarDeviasi & 7.10 & 5.21 & 8.76 & 5.87 \\
NilaiMaksimum Ideal & 150 & 150 & 150 & 150 \\
Nilai Minimum Ideal & 0 & 0 & 0 & 28 \\
Jumlah siswa & & 32 & & 0 \\
\hline
\end{tabular}

*) sumber data: hasil tes

Berdasarkan hasil analisis statistic deskriptif pada Tabel 4, menunjukkan bahwa pada kelompok eksperimen terdapat peningkatan skor rata-rata minat belajar siswa sebelum dan setelah perlakuan yaitu sebesar 16,06 dari 109,41 menjadi 125,47. Sementara pada kelas kontrol terjadi peningkatan sebesar 11,17 dari 96,61 menjadi 107,78 . Nilai tertinggi pada pretest dari kelas eksperimen sebesar 124 dan nilai terendah sebesar 98, sedangkan pada hasil posttest nilai tertinggi sebesar 135 dan nilai terendah sebesar 119. Sementara itu pada kelas kontrol, nilai terendah hasil pretest sebesar 81 dan nilai tertinggi sebesar 113, sedangkan pada kelas kontrol nilai terendah hasil posttest sebesar 97 dan nilai tertinggi sebesar 117.

Selanjutnya untuk mengetahui setiap interval, Tabel 5 berikut ini merupakan deskripsi dari setiap tingkatan nilai pretest dan posttest. 
Tabel 5. Nilai Pretes dan Postes

\begin{tabular}{|c|c|c|c|c|}
\hline \multirow{2}{*}{ Interval } & \multicolumn{2}{|c|}{ Kelas Eksperimen } & \multicolumn{2}{|c|}{ Kontrol } \\
\hline & Pretest & Posttest & Pretest & Posttest \\
\hline SangatTinggi $(80-100)$ & 6 & 17 & 0 & 3 \\
\hline Tinggi $(70-79)$ & 7 & 13 & 5 & 13 \\
\hline Sedang $(60-69)$ & 6 & 2 & 8 & 11 \\
\hline Rendah $(50-59)$ & 11 & 0 & 13 & 1 \\
\hline SangatRendah $(0-49)$ & 2 & 0 & 2 & 0 \\
\hline Jumlah siswa & \multicolumn{2}{|c|}{32} & \multicolumn{2}{|c|}{28} \\
\hline
\end{tabular}

Berdasarkan Tabel 5, frekuensi nilai pretest dan posttest, setelah diberikan pretest, hasilnya pada kelas eksperimen terdapat 6 mahasiswa yang berada pada kategori sangat tinggi dan sedang, 7 mahasiswa berada pada kategori tinggi, 11 orang mahasiswa berada pada kategori rendah, dan 2 orang berada pada kategori sangat rendah. Sementara itu, setelah dilaksanakan pembelajaran dengan pendekatan pendektan elearning berbasis edmodo dan diberikan posttest, terdapat 17 mahasiswa berada pada kategori sangat tinggi, 13 mahasiswa berada pada kategori tinggi dan 2 mahasiswa yang berada pada kategori sedang.

Sementara pada kelas kontrol, setelah diberikan pretest, hasilnya pada kelas tersebut terdapat 5 mahasiswa yang berada pada kategori tinggi, 8 mahasiswa berada pada kategori sedang, 13 orang mahasiswa berada pada kategori rendah, dan 2 orang berada pada kategori sangat rendah. Sementara itu, setelah dilaksanakan pembelajaran konvensional dan diberikan posttest, terdapat 3 mahasiswa berada pada kategori sangat tinggi, 13 mahasiswa berada pada kategori tinggi, 11 mahasiswa yang berada pada kategori sedang dan 1 orang berada pada kategori rendah.

\section{Pengujian Prasyarat Analisis}

Sebelum dilakukan analisis perbedaan pendekatan pembelajaran untuk mengetahui apakah terdapat perbedaan antara kedua kelas, terlebih dahulu dilakukan uji asumsi yang meliputi uji normalitas dan uji homogenitas. Berikut ini adalah hasil uji persyaratan tersebut

a. Uji Normalitas

Uji normalitas mempunyai tujuan untuk mengetahui apakah data hasil pretest dan posttest hasil belajar dan minat belajar siswa pada masing-masing kelas berasal dari populasi yang berdistribusi normal atau tidak. Pada penelitian ini uji normalitas menggunakan one sample Kolmogorov Smirnov Test.

Hasil uji yang dilakukan menggunakan bantuan Microsoft Excel 2013, menunjukkan seperti pada tabel berikut ini:

Tabel 6. Uji Normalitas

\begin{tabular}{ccccc}
\hline \multicolumn{5}{c}{ Tabel 6. Uji Normalitas } \\
Statistik & $\begin{array}{c}\text { Pretest } \\
\text { Ekperimen }\end{array}$ & $\begin{array}{c}\text { Postest } \\
\text { Eksperimen }\end{array}$ & $\begin{array}{c}\text { Pretest } \\
\text { Kontrol }\end{array}$ & $\begin{array}{c}\text { Postest } \\
\text { Kontrol }\end{array}$ \\
\hline N Sampel & 32 & 32 & 28 & 28 \\
Mean & 65,66 & 79,69 & 59,29 & 70,71 \\
Simpangan Baku & 12.089 & 7.713 & 11.300 & 8.914 \\
D $_{\mathrm{n}}=$ & 0.146 & 0.107 & 0.167 & 0.116 \\
KS Tabel & 0.240 & 0.240 & 0.257 & 0.257 \\
\hline
\end{tabular}

\section{Normal}

Tabel tersebut menunjukkan hasil uji normalitas untuk seluruh kelas baik pada hasil pretest dan posttest, nilai Kolmogorov Smirnov lebih besar dari Dn, sehingga data berasal dari data yang berdistribusi normal.

\section{b. Uji Homogenitas}

Uji homogenitas digunakan untuk mengetahui matriksvarians-kovarians kedua populasi dengan dua variabel dependen secara simultan itu homogen 
atau tidak. Uji homogenitas dilakukan dengan bantuan Microsoft Excel menggunakan Fisher F. Kriteria pengujian ditetapkan bahwa nilai signifikansi lebih dari 0,05 maka matriks varians-kovarians dari variabel dependen homogen.

Hasil uji homogenitas yang telah dilakukan terlihat pada tabel 7 berikut ini:

Tabel 7. Uji Homogenitas

\begin{tabular}{|c|c|c|c|c|}
\hline \multicolumn{5}{|c|}{ Uji Homogenitas Fisher } \\
\hline & $\begin{array}{l}\text { Hasil belajar } \\
\text { Eksperimen }\end{array}$ & $\begin{array}{r}\text { Hasil Belajar } \\
\text { Kontrol }\end{array}$ & $\begin{array}{r}\text { Minat Belajar } \\
\text { Ekperimen }\end{array}$ & $\begin{array}{r}\text { Minat Belajar } \\
\text { Kontrol } \\
\end{array}$ \\
\hline Mean Kelompok 1 & 67.375 & 59.286 & 109.406 & 96.607 \\
\hline Mean Kelompok 2 & 79.438 & 70.714 & 125.469 & 107.786 \\
\hline Beda 2 Mean & -12.063 & -11.429 & -16.063 & -11.179 \\
\hline Varian Kelompok 1 & 122.823 & 90.212 & 36.507 & 57.136 \\
\hline Varian Kelompok 2 & 61.351 & 72.952 & 18.967 & 32.767 \\
\hline N Kelompok 1 & 32 & 28 & 32 & 28 \\
\hline N Kelompok 2 & 32 & 28 & 32 & 28 \\
\hline DF1 & 31 & 27 & 31 & 27 \\
\hline DF2 & 31 & 27 & 31 & 27 \\
\hline Batas Kritis/Tingkat Signifikansi & 0.05 & 0.05 & 0.05 & 0.05 \\
\hline F Hit $(\mathrm{df} 1=31, \mathrm{df} 2=31)$ & 2.002 & 1.237 & 1.925 & 1.737 \\
\hline P Value (left tailed) & 0.971 & 0.708 & 0.963 & 0.923 \\
\hline P Value (right tailed) & 0.029 & 0.292 & 0.0365 & 0.0775 \\
\hline P Value (2 tailed) & 0.058 & 0.585 & 0.0730 & 0.155 \\
\hline KeteranganHomogenitas & & Homogen & & \\
\hline
\end{tabular}

Hasil uji homogenitas multivariat data sebelum perlakuan diperoleh nilai $\mathrm{P}$ value ( 2 Tailed) lebih besar dari tingkat signifikansi 0,05 , ini berarti bahwa uji homogenitas pada kedua kelompok dengan dua variabel dependen terpenuhi.

Sementara itu, untuk mengetahui apakah terjadi peningkatan hasil belajar setelah diberikan pendekatan berbasis edmodo. Uji yang digunakan untuk mengetahui terjadinya peningkatan kemampuan hasil belajar adalah uji t-paired terhadap rata-rata skor postttest dengan pretest untuk kedua kelas.

Hipotesis statistik yang digunakan adalah:

$$
\begin{aligned}
& \mathrm{H}_{0}: \mu_{1} \leq \mu_{2} \\
& \mathrm{H}_{1}: \mu_{1}>\mu_{2}
\end{aligned}
$$

Dengan $\mu_{1}$ merupakan rata-rata skor posttest pada pendekatan berbasis edmodo, dan $\mu_{2}$ merupakan rata-rata skor pretest pada pendekatan edmodo. Statistik uji yang digunakan adalah sebagai berikut (Walpole, 1995: 305):

$$
\mathrm{t}=\frac{\overline{\mathrm{d}}_{\mathrm{e}}-\mathrm{d}_{0}}{\mathrm{~s}_{\mathrm{de}} / \sqrt{\mathrm{n}}}
$$

Kriteria keputusannya adalah $\mathrm{H}_{0}$ ditolak jika: $t_{h i t}>t_{\alpha}$ dengan $\mathrm{db}=\mathrm{n}-1$ atau $\mathrm{H}_{0}$ ditolak jika nilai sig $\leq 0,05$, untuk pengujian yang dilakukan dengan bantuan program SPSS 21 for windows.

Selain untuk menguji hasil belajar mahasiswa, peningkatan minat belajar siswa juga dilakukan uji t paired. Pengujian dilakukan setelah diberikan pendekatan berbasis edmodo. Uji yang digunakan untuk mengetahui terjadinya peningkatan minat belajar adalah uji t-paired terhadap 
rata-rata skor posttest dengan pretest untuk kedua kelas. adalah:

Hipotesis statistik yang digunakan

$$
\begin{aligned}
& \mathrm{H}_{0}: \mu_{1} \leq \mu_{2} \\
& \mathrm{H}_{1}: \mu_{1}>\mu_{2}
\end{aligned}
$$

Dengan $\mu_{1}$ merupakan rata-rata skor posttest pada pendekatan berbasis edmodo, dan $\mu_{2}$ merupakan rata-rata skor pretest pada pendekatan edmodo. Statistik uji yang digunakan adalah sebagai berikut (Walpole, 1995: 305):

$$
\mathrm{t}=\frac{\overline{\mathrm{d}}_{\mathrm{e}}-\mathrm{d}_{0}}{\mathrm{~s}_{\mathrm{de}} / \sqrt{\mathrm{n}}}
$$

Kriteria keputusannya adalah $\mathrm{H}_{0}$ ditolak jika: $t_{\text {hit }}>t_{\alpha}$ dengan $\mathrm{db}=\mathrm{n}-1$ atau $\mathrm{H}_{0}$ ditolak jika nilai sig $\leq 0,05$, untuk pengujian yang dilakukan dengan bantuan program SPSS 21 for windows.
1) Hasil Belajar

Uji hipotesis yang dilakukan setelah semua data dari hasil penelitian terkumpul. Pengujian hipotesis ini dilakukan dengan bantuan program SPSS 20 for Windows yaitu dengan teknik analisis Paired Samples T-Test. Taraf signifikan uji sampel bebas Paired-Samples T-Test adalah 0,05, sedangkan convidence interval $95 \%$. Uji hipotesis dengan uji kesamaan dua rata-rata dilakukan untuk mengetahui apakah terdapat perbedaan rata-rata secara signifikan antara hasil posttest dua sampel penelitian. Hipotesis pada penelitian ini adalah: H0: pendekatan pembelajaran berbasis edmodo terhadap hasil belajar tidak lebih baik dengan pendekatan pembelajaran konvensional. Ha: pendekatan pembelajaran berbasis edmodo terhadap hasil belajar lebih baik dengan pendekatan pembelajaran konvensional.

c. Uji Hipotesis Penelitian

Tabel 8. Uji t Hasil Belajar

\begin{tabular}{cccccc}
\hline Kelas & Mean & Thitung & Ttabel & df & Asy.Sig(2-tailed) \\
\hline Eksperimen & 79,69 & 10,097 & 2,039 & 31 & 0,000 \\
\hline Konvensional & 70,71 & 7,166 & 2,052 & 27 & 0,000 \\
\hline Berdasarkan & tabel di & atas & hasil & berbasis & edmodo
\end{tabular}

Berdasarkan tabel di atas, hasil analisis uji paired t-test menunjukkan bahwa nilai t hitung dari pretest posttest kelompok eksperimen sebesar 10,097 dan t hitung dari preteset posttest kelas konvensional sebesar 7,166. Dari data tersebut terlihat nilai $\mathrm{t}$ hitung $>\mathrm{t}$ tabel pada kedua kelompok, sehingga terdapat pengaruh perbedaan kinerja padakedua kelompok kelas.

Selanjutnya, mean pada kelompok eksperimen lebih besar dari mean kelompok kontrol, sehingga dapat disimpulkan bahwa dengan penerapan pembelajaran elearning berbasis edmodo terhadap hasil belajar lebih baik dibandingkan dengan pendekatan dengan pembelajaran konvensional di PGSD STKIP Muhammadiyah Muara Bungo. Dan terdapat pengaruh yang signifikan setelah dilakukan pembelajaran elearning berbasis edmodo terhadap hasil belajar mahasiswa.

2) Minat Belajar

Selain menguji hasil belajar, langkah selanjutny adalah uji hipotesis yang dilakukan setelah semua data dari hasil penelitian terkumpul. Pengujian hipotesis ini dilakukan dengan bantuan program SPSS 20 for Windows yaitu dengan teknik analisis Paired Samples T-Test. Taraf signifikan uji sampel bebas PairedSamples T-Test adalah 0,05, sedangkan convidence interval 95\%. Uji hipotesis dengan uji kesamaan dua rata-rata dilakukan untuk mengetahui apakah terdapat perbedaan rata-rata secara signifikan antara hasil posttest dua sampel penelitian. Hipotesis pada penelitian ini adalah: H0: pendekatan pembelajaran berbasis edmodo terhadap minat belajar tidak lebih baik dengan pendekatan pembelajaran konvensional. Ha: 
pendekatan pembelajaran berbasis edmodo

pendekatan pembelajaran konvensional.

terhadap minat belajar lebih baik dengan

Tabel 9. Uji t Minat Belajar

\begin{tabular}{cccccc}
\hline Kelas & Mean & Thitung & Ttabel & df & Asy.Sig(2-tailed) \\
\hline Eksperimen & 125,47 & 19,068 & 2,039 & 31 & 0,000 \\
\hline Konvensional & 107,79 & 13,662 & 2,052 & 27 & 0,000 \\
\hline
\end{tabular}

Berdasarkan tabel di atas, hasil analisis uji paired t-test menunjukkan bahwa nilai $t$ hitung dari pretest posttest kelompok eksperimen sebesar 19,068 dan $\mathrm{t}$ hitung dari preteset posttest kelas konvensional sebesar 13,662. Dari data tersebut terlihat nilai $\mathrm{t}$ hitung $>\mathrm{t}$ tabel pada kedua kelompok, sehingga terdapat pengaruh perbedaan kinerja pada kedua kelompok kelas.

Selanjutnya, mean pada kelompok eksperimen lebih besar dari mean kelompok kontrol, sehingga dapat disimpulkan bahwa dengan penerapan pembelajaran elearning berbasis edmodo terhadap minat belajar lebih baik dibandingkan dengan pendekatan dengan pembelajaran konvensional di PGSD STKIP Muhammadiyah Muara Bungo. Dan terdapat pengaruh yang signifikan setelah dilakukan pembelajaran elearning berbasis edmodo terhadap minat belajar mahasiswa.

\section{SIMPULAN DAN SARAN}

Berdasarkan hasil penelitian yang sudah dilaksanakan, simpulan dari penelitian ini adalah sebagai berikut: (1) Hasil ujicoba instrument penelitian, baik validitas maupun reliabilitas, soal dapat digunakan dalam penelitian, (2) Untuk Hasil Belajar nilai ratarata untuk kelas eksperimen meningkat sebesar 12,06, sementara untuk kelas kontrol meningkat sebesar 11,45. (3) Untuk minat belajar siswa nilai rata-rata kelas eksperimen meningkat sebesar 16,06 sedangkan pada kelas kontrol meningkat sebesar 11,07.(4) Uji persyaratan yang meliputi normalitas dan homogenitas berada pada seluruh kelas berdistribusi normal dan homogen. (5) terdapat pengaruh yang signifikan dengan pembelajaran elearning berbasis edmodo terhadap hasil belajar serta minat berlajar mahasiswa

\section{DAFTAR PUSTAKA}

Anisyah. 2000. Analisa dan Desain Sistem Informasi. Yogyakarta: Andi.

Buyens, J. 2001. Web Database Development. Jakarta: Elex Media Komputindo.

Dhanta, R. 2009. Pengantar Ilmu Komputer. Surabaya: Indah.

Hamalik, O. 2011. Proses Belajar Mengajar. Jakarta: Bumi Aksara.

Hidayat, Puput Wahyu., \& Widjajanti, Djamilah Bondan. 2018. Analisis Kemampuan Berpikir Kreatif dan Minat Belajar Siswa dalam Mengerjakan Soal Open Ended dengan Pendekatan CTL. Phytagoras: Jurnal Pendidikan Matematika, Volume 13, nomor (1):65.

Kristanto, Harianto. 2004. Konsep dan Perancangan Database. Yogyakarta: Andi.

Mudjiono \& Dimyati . 2013. Belajar dan Pembelajaran. Jakarta: Rineka Cipta.

Muhson, Ali. 2009. Peningkatan Minat Belajar dan Pemahaman Mahasiswa Melalui Penerapan Problem-Based Learning. Jurnal Kependidikan Universitas Negeri Yogyakarta, Volume 39, nomor (1), 171 182.

Presman, R. S. 2012. Rekayasa Perangkat Lunak (Pendekatan Praktisi) Edisi 7: Buku 1. Yogyakarta: Andi.

Sardiman. 2011. Interaksi dan Motivasi Belajar Mengajar. Jakarta: Rajawali Press.

Slameto. 2013. Belajar dan Faktor-faktor yang Mempengaruhinya. Jakarta: Rineka Cipta.

Sudjana, N. 2009. Penilaian Hasil Proses Belajar Mengajar. Bandung: PT. Remaja Rosdakarya.

Uno, H.B. 2011. Teori Motivasi dan Pengukurannya: Analisis di Bidang Pendidikan. Jakarta: Bumi Aksara. 